\title{
29. WELL LOGGING OF THE SEDIMENTS AND BASEMENT COMPLEX ON THE WALVIS RIDGE1
}

\author{
Philip D. Rabinowitz, Department of Oceanography, Texas A\&M University, College Station, Texas \\ and \\ Peter E. Borella, Deep Sea Drilling Project, Scripps Institution of Oceanography, La Jolla, California
}

\begin{abstract}
The results of two geophysical well logs obtained during Glomar Challenger Cruise 74 on the Walvis Ridge are presented. A density log was obtained on the sediments at Site 527; a sonic log was obtained on the sediments and upper $75 \mathrm{~m}$ of the basement complex at Site 528. Natural gamma ray and caliper traces accompanied each log. The sediments consisted primarily of oozes and chalk, the latter increasing with depth. Varying amounts of volcanogenic sediments are present; they increase toward the bottom of the hole. The top of the basement complex is characterized by smooth acoustic reflectors on seismic profiles. The rocks recovered within the basement complex consisted of basalts with interlayered sediments.

The correlation of the downhole well logs with the recovered sediments is excellent. The clayey areas, slump deposits, and breccias all give relatively high gamma ray and low density and sonic readings. Most of the interval between the Cretaceous/Tertiary boundary and the basement complex is identified by relatively high gamma ray values, owing to the enriched amounts of clay and volcanogenic materials found there as compared to carbonate sections.

Within the basement complex, where the recovery is poorest, the sonic log enables us to reconstruct the hole. In the upper $75 \mathrm{~m}$ of the basement complex, approximately half the material is believed to be igneous and the other half sedimentary in origin. We recovered most of the basalts we drilled $(88 \%)$ and much less of the sediments $(32 \%)$. Our sonobuoy results indicate that the ratio of sediments to basalt increases with depth for a further $225 \mathrm{~m}$, until true oceanic basement with a typical oceanic velocity structure is observed. Paleontological results strongly suggest that the processes forming this upper $300 \mathrm{~m}$ of the basement complex of the Walvis Ridge were completed within a short time interval. Sound sources of greater energy than previously used in the Walvis Ridge area should enable us to profile the true oceanic basement here.
\end{abstract}

\section{INTRODUCTION}

During Leg 74 , a suite of closely spaced holes was drilled at different water depths on the flank of the Walvis Ridge in the southeast Atlantic Ocean (Fig. 1). Sampling of sediments in close geographic proximity over a wide range of water depths allows us to assume that a rather uniform supply of carbonate material reached the seafloor at any given time and makes it possible to address several problems relating to the history of carbonate preservation and the timing and nature of changes in the bottom water circulation of the South Atlantic Ocean. Further, the composition and origin of the rocks forming the Walvis Ridge and hence its evolution have not been fully understood. The primary objectives of the Leg 74 cruise were to address the very fundamental problems relating to the paleoenvironments of the South Atlantic Ocean during the late Mesozoic and Cenozoic and to the origin of the Walvis Ridge (Moore, Rabinowitz, et al., in press).

Of the five sites drilled in water depths ranging from $\simeq 1000$ to $4000 \mathrm{~m}$ (Fig. 1, Table 1), three penetrated the "smooth" basement reflectors observed on seismic reflection profiles of the area and recovered rocks that are important for our understanding of the evolution of the Walvis Ridge. We attempted in-hole logging experiments on two of the holes in which basement was penetrated (Holes 527 and 528). Although we did not obtain

\footnotetext{
${ }^{1}$ Moore, T. C., Jr., Rabinowitz, P. D., et al., Init. Repts. DSDP, 74: Washington (U.S. Govt. Printing Office).
}

complete suites of well logs for each of these holes, we obtained information significant enough to warrant discussion. This included a density log in the sediments of Hole 527, although within the basement complex the logging did not penetrate deeply enough to enable us to draw useful conclusions, and a sonic log in both the sediments and basement complex of Hole 528 .

The downhole logs could be relatively well correlated with the sediments recovered at Sites 527 and 528. Within the basement complex the recovery was much poorer than in the sediment column above, and major use of the downhole data here is to identify rock types where recovery was poor. The well logs, when considered together with the rocks recovered in the basement complex and the sonobuoy wide-angle reflection/refraction information, give us important new information about the composition of the upper part of the Walvis Ridgethat is, the part characterized by the smooth basement reflectors.

There are few published logging data for basaltic oceanic basement. Kirkpatrick (1979 a, b) reported data from DSDP Hole 396 (Leg 46) for the upper $200 \mathrm{~m}$ of 10 m.y. old ocean crust in the central Atlantic Ocean. Salisbury et al. (1980) presented geophysical logging data for the upper $366 \mathrm{~m}$ of early Aptian ocean crust from DSDP Hole 417D at the southern end of the Bermuda Rise in the central Atlantic Ocean. The results from these two holes present comprehensive geophysical data on the in situ properties of the oceanic basement. Boyce (1981) discussed the basalt logs in a major Cretaceous sill complex in a region of Jurassic ocean crust 


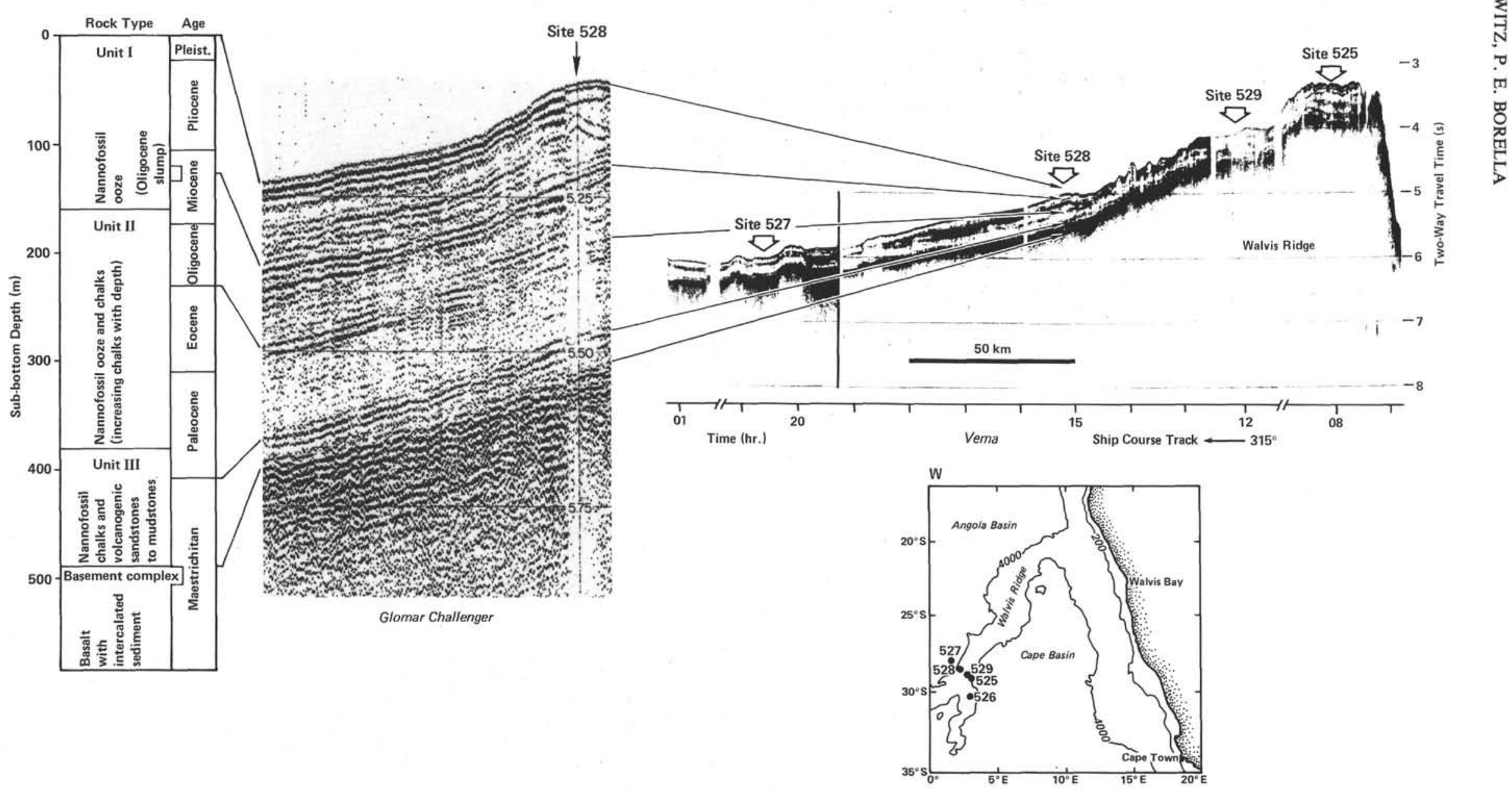

Figure 1. Glomar Challenger seismic reflection profile taken on approach to Site 528 and its correlation to lithology. Vema seismic reflection profile across Walvis Ridge transect also given to demonstrate continuity of reflectors. 
Table 1. Leg 74 coring summary.

\begin{tabular}{|c|c|c|c|c|}
\hline Hole & Latitude & Longitude & $\begin{array}{c}\text { Water } \\
\text { Depth } \\
\text { (m) }\end{array}$ & $\begin{array}{l}\text { Penetration } \\
\text { (m) }\end{array}$ \\
\hline 525 & $29^{\circ} 04.24^{\prime} \mathrm{S}$ & $02^{\circ} 59.12^{\prime} \mathrm{E}$ & 2467 & 3.6 \\
\hline $525 \mathrm{~A}$ & $29^{\circ} 04.24^{\prime} \mathrm{S}$ & $02^{\circ} 59.12^{\prime} \mathrm{E}$ & 2467 & 678.1 \\
\hline 525B & $29^{\circ} 04.24^{\prime} \mathrm{S}$ & $02^{\circ} 59.12^{\prime} \mathrm{E}$ & 2467 & 285.6 \\
\hline 526 & $30^{\circ} 07.36^{\prime} \mathrm{S}$ & $03^{\circ} 08.28^{\prime} \mathrm{E}$ & 1054 & 6.3 \\
\hline $526 \mathrm{~A}$ & $30^{\circ} 07.36^{\prime} \mathrm{S}$ & $03^{\circ} 08.28^{\prime} \mathrm{E}$ & 1054 & 228.8 \\
\hline $526 \mathrm{~B}$ & $30^{\circ} 07.36^{\prime} \mathrm{S}$ & $03^{\circ} 08.28^{\prime} \mathrm{E}$ & 1054 & 28.3 \\
\hline $526 \mathrm{C}$ & $30^{\circ} 07.36^{\prime} \mathrm{S}$ & $03^{\circ} 08.28^{\prime} \mathrm{E}$ & 1054 & 356.0 \\
\hline 527 & $28^{\circ} 02.49^{\prime} \mathrm{S}$ & $01^{\circ} 45.80^{\prime} \mathrm{E}$ & 4428 & 384.5 \\
\hline 528 & $28^{\circ} 31.49^{\prime} \mathrm{S}$ & $02^{\circ} 19.44^{\prime} \mathrm{E}$ & 3800 & 555.0 \\
\hline $528 \mathrm{~A}$ & $28^{\circ} 31.16^{\prime} \mathrm{S}$ & $02^{\circ} 18.97^{\prime} \mathrm{E}$ & 3815 & 130.5 \\
\hline 529 & $28^{\circ} 5.83^{\prime} \mathrm{S}$ & $02^{\circ} 46.08^{\prime} \mathrm{E}$ & 3035 & 417.0 \\
\hline
\end{tabular}

in the Nauru Basin of the western Pacific Ocean. We believe that the basement logging results presented in this chapter are the first published for an oceanic aseismic ridge.

\section{LOGGING METHODS}

Accompanying the density log obtained at Site 527 and the sonic $\log$ at Site 528 were natural gamma ray and caliper trace. The instruments used were standard oilfield downhole logging tools with surface recording equipment. Gearhart-Owen provided the apparatus and an operating engineer. A brief description of the tools used in Holes 527 and 528 follows; the reader is referred to Schlumberger $(1972 a, b)$ and Pirson (1963), among others, for a more comprehensive discussion of the logging tools and interpretations.

The density tool consists of a directional gamma ray source and two directional gamma ray detectors spaced along the tool at different distances from the source. The emitted gamma rays interact with the electrons of matter around the borehole and the gamma ray detectors respond to the back-scattered rays. The intensity of the back-scattered rays depends on the electron density of the matter penetrated; this in turn is related to the density of the surrounding rock. The tool investigates to a maximum depth of about $15 \mathrm{~cm}$; however, most of the signal comes from within about $7-8 \mathrm{~cm}$ of the formation.

The sonic velocity tool consists of two sets, each consisting of one transducer and two receivers. The transit time of the elastic wave signal is measured over approximately $0.6 \mathrm{~m}$ along the borehole wall. Thus, the measured velocities can be correct only for intervals thicker than $\simeq 0.6 \mathrm{~m}$. The first arrival signals penetrate only a few centimeters into the formation. The velocities obtained are thus greatly affected by fractures, irregular porosity, or drilling damage. Accordingly, the velocity obtained by the sonic tool is quite typically the minimum velocity in that interval.

The natural gamma ray tool measures the total natural gamma ray emission of rocks from the formation. Nearly all of the radiation we encounter is the result of gamma rays produced by potassium 40 and the decay daughter products in uranium and thorium series. Since the tool used on Leg 74 was nonspectral, no distinction can be made between radiation arising from the decay of $\mathrm{K}^{40}$ and the elements of the uranium and thorium decay series. The distance investigated by the gamma ray log was $\sim 0.30 \mathrm{~m}$ in the sediments and $\sim 0.15 \mathrm{~m}$ in the basalts.

The caliper tool measures the changes in diameter of the hole with depth, simultaneously with the other measurements. The rugosity of the hole is obviously an important criterion to be considered in evaluating the logs. Another important test of the precision of the logs involves cross-plotting the different logged measurements (e.g., sonic versus density) and comparing the results with the laboratory data, but we did not obtain enough different logs from each hole to accomplish this.

\section{RELATIONSHIP OF LITHOLOGY AND AGE TO SEISMIC REFLECTION PROFILES}

A single-channel analog seismic reflection profile collected aboard Vema, from Lamont-Doherty Geological
Observatory, across the Walvis Ridge transect is given in Figure 1. The original site selections were made from this profile. Minor modifications in the site selections were made on the basis of the seismic data collected during a preliminary site survey by Thomas B. Davie of the University of Capetown (Rabinowitz and Simpson, 1979, and this volume). Figure 1 also includes an enlarged portion of the seismic profile taken in the vicinity of DSDP Site 528 by instruments aboard Glomar Challenger while the ship was en route to the site, as well as the lithology, age, and depth summary of the drilling results at Site 528. The basal dark reflector (acoustic basement) observed along the entire profile is rather smooth, in comparison to oceanic basement normally associated with seafloor spreading processes (e.g., Ewing and Ewing, 1971). This reflector coincides with the top of the basement complex and recovered basalts drilled at Sites 525,527 , and 528, and its "smoothness" may be a manifestation of that complex, which consists of basalt with intercalated sediments. The top of the prominent reflector observed at $\simeq 0.06 \mathrm{~s}$ (two-way traveltime) above the basement reflector at Site 528 corresponds well to the top of Lithologic Unit III drilled there (very close to the Cretaceous/Tertiary boundary) and to the lithologic change from nannofossil oozes and chalks to nannofossil chalks and volcanogenic mudstones and siltstones. This reflecting horizon is continuous from Site 525 in the shallow part of the transect to the base of the transect at Site 527. In all four sites drilled on this seismic line (Sites 525, 527, 528, and 529) this reflector corresponds well with rocks recovered near the Cretaceous/Tertiary boundary. At $\simeq 0.22 \mathrm{~s}$ (two-way traveltime) above basement, there is a reflector which corresponds well to the Eocene/Oligocene boundary and the lithologic change from oozes to oozes and chalks near the top of Unit II. At $\simeq 0.33 \mathrm{~s}$ (two-way traveltime) above basement another prominent reflector near the base of Unit I may relate to reworked material of Oligocene to Eocene age observed within the Miocene at Site 528.

\section{THE SEDIMENT COLUMN}

The sediment recovered at Sites 527 and 528 consists of oozes for the top $\simeq 110 \mathrm{~m}$ below the seafloor, followed by alternating beds of oozes and chalks; the amounts of chalks increase with depth. There are varying amounts of volcanogenic sediments, which also increase toward the bottom of the holes. The sediments are cyclic in nature; cycles are small-scale $(10-100 \mathrm{~cm})$, probably of slump and turbidite origin, and appear more dominant toward the bottom of the hole. Oxidation/reduction and dissolution cycles are also observed (Borella, this volume).

The density log obtained at Site 527 is given in Figure 2; the sonic log obtained at Site 528 is given in Figure 3. Associated with each figure is a gamma ray caliper trace. Also included are plots of the laboratory-determined wet-bulk densities and sonic velocities. These densities are for the most part less than the densities observed on the logging record, primarily because of the effect of overburden pressure (Hamilton, 1965, 1976). Laboratory-determined sonic velocities are also general- 


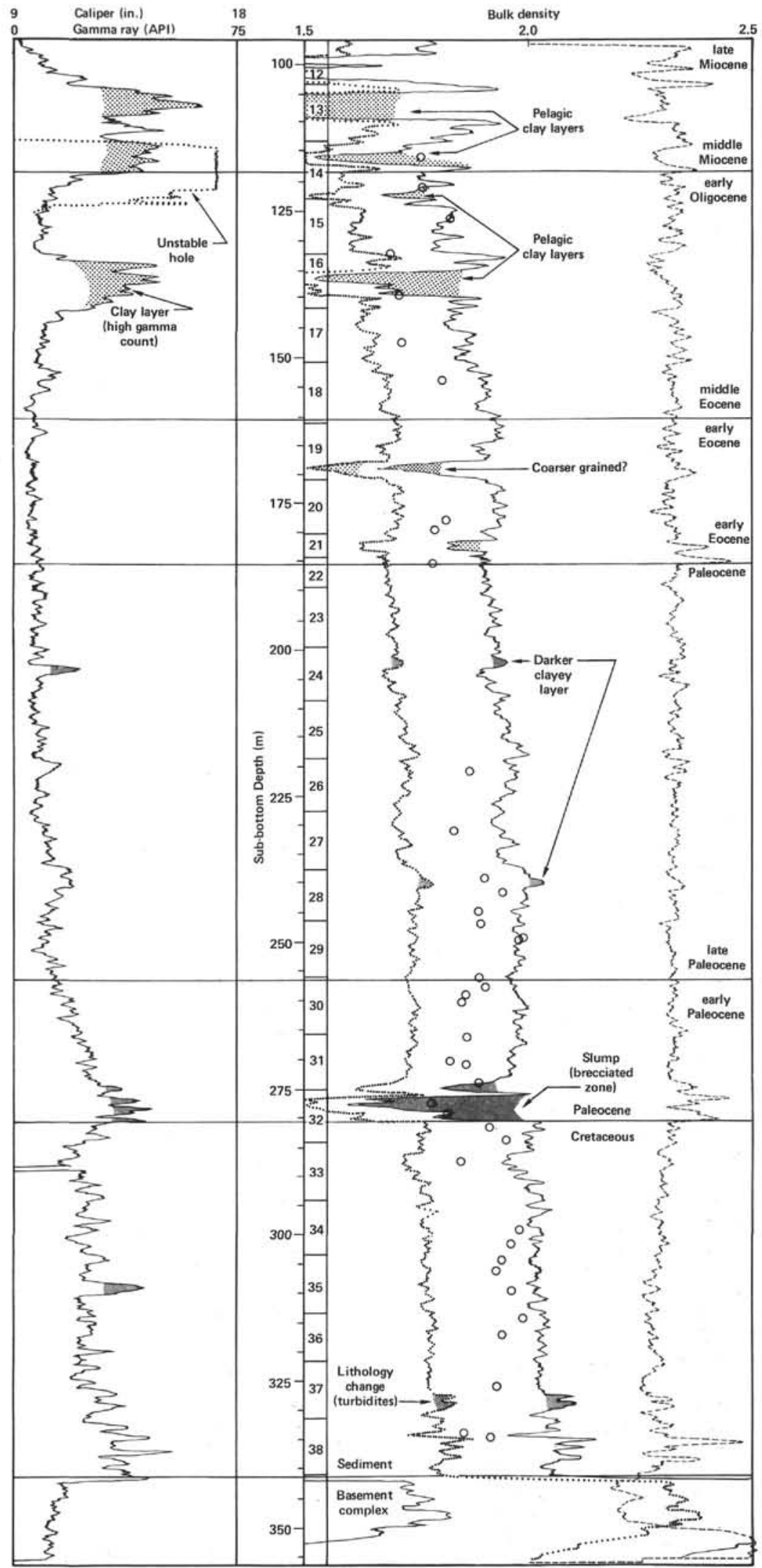

Figure 2. Density log at Site 527. Key to symbols (right graph): $-=P(B)$ bulk density $\left(1.5-2.5 \mathrm{~g} / \mathrm{cm}^{3}\right) ;-\cdots=\phi(C D L)$ compensated density $\log$; $\triangle \mathrm{P}$ correction factor for mudcake density and hole rugosity; $\mathrm{o}=$ laboratory-determined wet-bulk density. Key to symbols (left graph): - - $=$ GR (gamma ray $\log ) ;-\cdots--=$ caliper trace $(9-18$ in. $)$. 
ly less than those determined from the downhole logs (Boyce, 1980), though in some parts of the hole they are greater. In these instances, hole washout, observed from the caliper traces, explains the discrepancy. At Site 528, the sediment part of the hole above basement was for large portions unstable, thus creating difficulties in interpreting the sonic log.

\section{Site 527 Sediment Log}

The correlation of the density and the gamma ray logs with the recovered sediment is excellent at Site 527. An increase in density with depth $(\simeq 1.85$ to $2.00 \mathrm{~g} /$ $\mathrm{cm}^{3}$ ) is consistent with the increase in the chalk/ooze ratio with depth. From 104-118 m and 131-140 m subbottom, there are large increases in the gamma ray log and large negative spikes in the density log (Fig. 2) that correspond to recovered pelagic clay layers. The $\mathrm{CaCO}_{3}$ content in these layers is less than $20 \%$, compared with over $90 \%$ above and below. These two clay units were deposited between middle Eocene and late Miocene time, when sedimentation rates ranged from close to zero to $0.16 \mathrm{~cm} / 10^{3} \mathrm{y}$. Cyclic sedimentation patterns repeat about every $1 \mathrm{~m}$, with gradational contacts between the cycles. There is no significant change in grain size between the clay layers and the ooze and chalks (Borella, this volume). Hiatuses are recognized between the early Oligocene and middle Miocene and between the late Miocene and early Pliocene (see site reports, this volume). The clay layers probably represent dissolution cycles. Site 527 , the deepest site in the transect, was probably at or close to a fluctuating CCD during the time intervals of deposition of the clay layers.

At $\simeq 168$ and $182 \mathrm{~m}$ sub-bottom, negative density spikes are again observed. The cores show a decrease in carbonates and an increase in silt-sized material (Borella, this volume). Distinct color changes can also be observed at these intervals. There is no increase in the gamma ray $\log$ to correspond with the density decrease. The coarser-grained sediment in these layers may not be radiogenic. The negative spike at $182 \mathrm{~m}$ (an area of poor recovery) is located just above the Paleocene/Eocene boundary. Both of the negative spike areas are located in alternating cycles of ooze and chalk which repeat every $10-50 \mathrm{~cm}$.

Positive density and gamma ray spikes are observed at $202 \mathrm{~m}$ and $240 \mathrm{~m}$ sub-bottom. They correlate with a red clay and a dark brown layer, respectively. Carbonate content in the red clay layer is $\simeq 1 \%$ and in the dark brown layer $\simeq 58 \%$ (see site reports, this volume). The increased density is attributed to a higher degree of compaction.

A large negative density spike and positive gamma ray spike are observed just above the Cretaceous/Tertiary boundary. Carbonate content within this interval (274-380 m sub-bottom) is very low $(<15 \%)$. Colors alternate with red and dark brown beds dominant. The alternating colored cycles and sediments are interpreted to represent oxidation/reduction cycles superimposed on episodic submarine movements (Borella, this volume) or slumps. The recovered sediments are brecciated. Since similar sedimentary sequences are found above the Cre-
taceous/Tertiary boundary at three other sites along our transect, we believe that the breccias and the cyclic sediments are indicative of the geological environment at this time.

A significant increase in the gamma ray record from the interval immediately above the Cretaceous/Tertiary boundary to the contact with the basement $(341.5 \mathrm{~m}$ sub-bottom) is attributed to the increased amount of clays and volcanogenic and shallow-water sediments which were transported to the deposition site, either by turbidity currents or slumps. A large positive spike in the gamma ray log at $308 \mathrm{~m}$ sub-bottom correlates with an ash layer overlying a nannofossil mudstone layer. Evidence of current activity is preserved in the sediments in the form of parallel and cross laminations, graded bedding, and displaced shallow-water sediments. The positive spike in the density log at $327.6 \mathrm{~m}$ sub-bottom corresponds to a distinct color change in the sediment. The sediments below have a lower carbonate content than the beds immediately above.

\section{Site 528 Sediment Log}

The irregularity of the sonic velocity log record within the sediments is a reflection of the poor hole conditions (see caliper trace, Fig. 3). However, in areas where the caliper indicates a narrow hole diameter several observations and correlations can be made.

In the upper $\simeq 170 \mathrm{~m}$ of the hole, the velocities are nearly constant $(1.80 \mathrm{~km} / \mathrm{s})$ and consistently above the sonic velocities measured in the laboratory. Then velocities gradually increase to the maximum value found in the sediments at $\simeq 370 \mathrm{~m}(2.37 \mathrm{~km} / \mathrm{s})$.

An increase in the gamma ray log record indicates higher clay content just above the Cretaceous/Tertiary boundary, as do the observations at Site 527 . This is supported by low carbonate values within this interval (see site reports, this volume). Red clayey beds alternating with light gray pelagic intervals are commonly observed in this interval. The sonic velocity record shows a decrease in velocities. The sediments here, like those at Site 527, are brecciated and are interpreted to be slump or turbidite deposits.

From below the Cretaceous/Tertiary boundary ( $407 \mathrm{~m})$ to the contact with the basement complex, the gamma ray log shows a similar increase to that observed in Hole 527. The sedimentary sequence consists of alternating beds of slump deposits and pelagic oozes with high amounts of volcaniclastic sediments. Greenish-colored turbidites and slump deposits alternate with lightercolored pelagic oozes.

\section{THE BASEMENT COMPLEX}

The top of the basement complex was first encountered in Hole 528 at $474 \mathrm{~m}$ sub-bottom (core 39; $4274 \mathrm{~m}$ below sea level) and consisted of massive plagioclase phyric basaltic rocks. After $\simeq 15 \mathrm{~m}$ of basalt recovery, we encountered sediment units intercalated between basaltic rock units. These sequences of alternating basaltic rocks and sedimentary units were observed for the entire $80 \mathrm{~m}$ that the basement complex was cored. The basalts were all subophitic in texture. They consisted of units of 


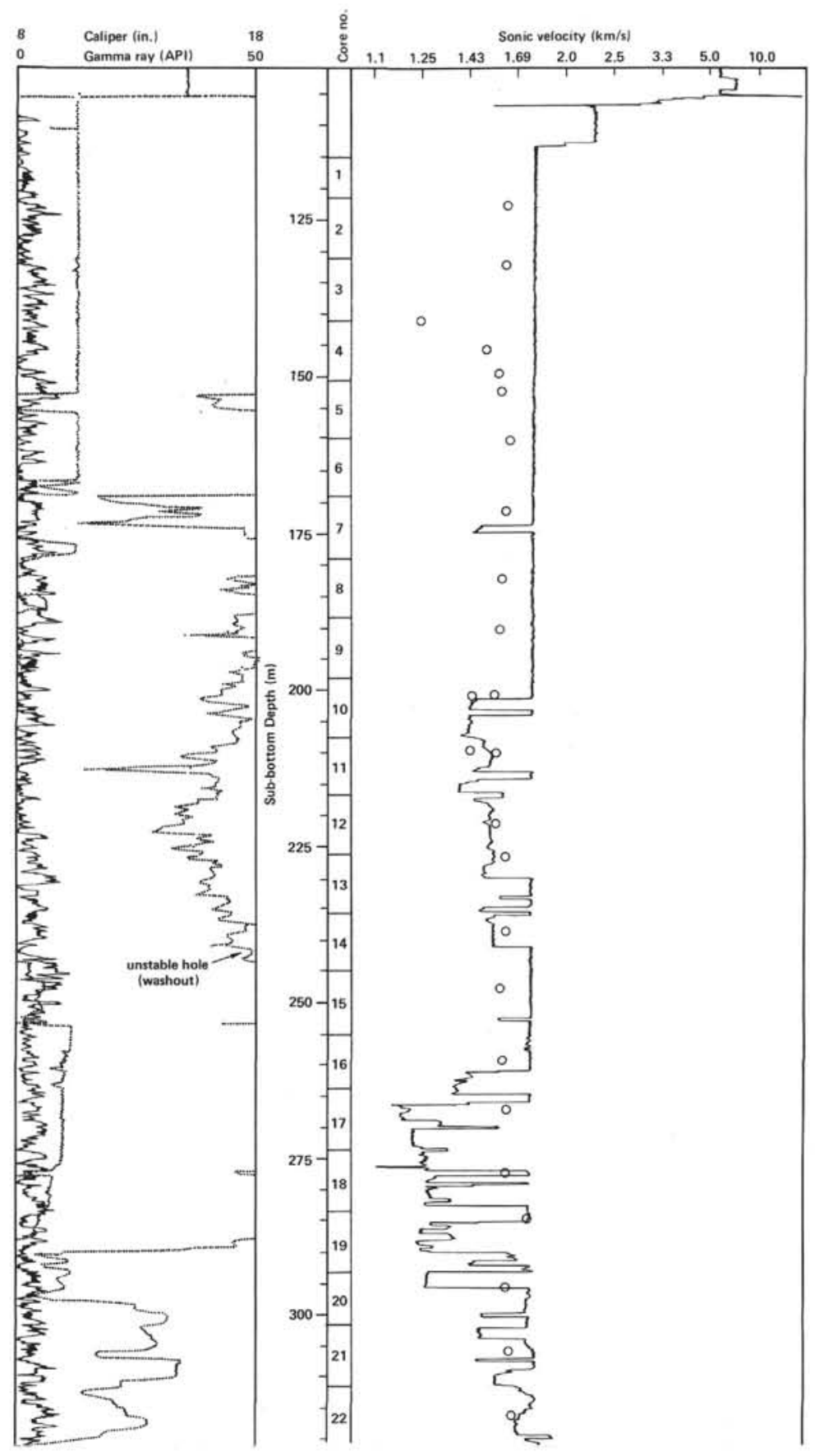

Figure 3. Sonic velocity $\log$ at Site 528 . Horizontal scale $0-10.0 \mathrm{~km} / \mathrm{s}$ (nonlinear). Key to symbols (right graph): Laboratory determinations of sonic velocity, made parallel to bedding (o), made perpendicular to bedding $(\times)$, of basalts parallel to bedding $(\otimes)$, of basalts perpendicular to bedding (ख). Key to symbols (left graph): caliper trace (8-18 in.).

medium-grained to coarsely grained, sparsely to highly plagioclase phyric with few vesicles and with few olivine phenocrysts (generally altered to clay minerals) as well as units of fine- to medium-grained aphyric basalts with vesicles ranging from 0 to $35 \%$ of the rock. The sedimentary rocks interlayered between the basalts consisted of volcanogenic turbidite sequences and indurated nannofossil chalks and limestones to carbonate mud- stones. Some shell fragments (Inoceramus) were observed within the limestones. The carbonate content varied from $\simeq 20$ to $60 \%$. The oldest sediments above the basement complex contained mid-Maestrichtian foraminiferal (Globotruncana gansseri Zone) and nannofossil (upper Arkhangelskiella cymbiformis Zone) zones only slightly younger than those observed in the sediments intercalated within the basalts $\simeq 70 \mathrm{~m}$ below the top of 


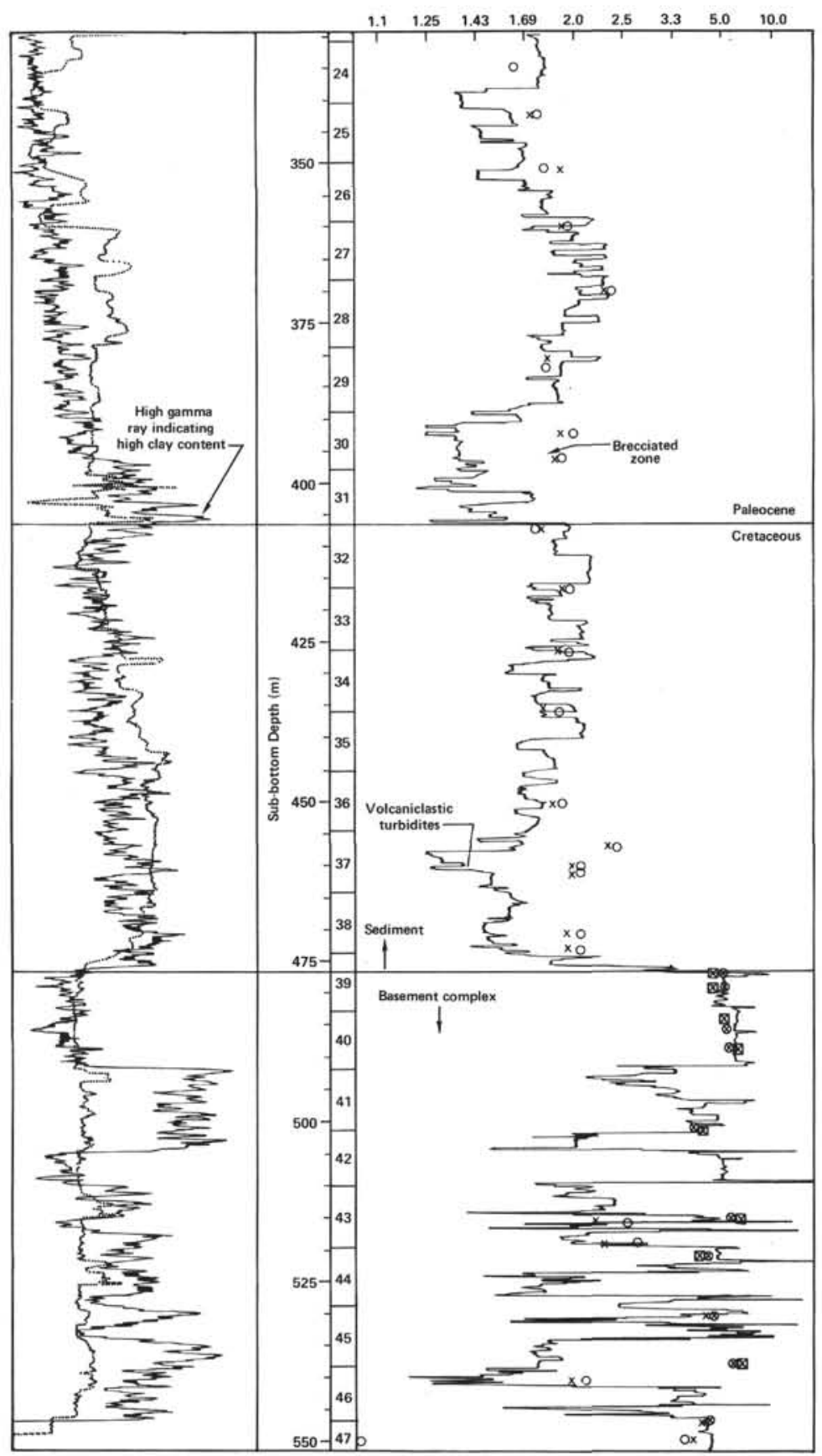

Figure 3. (Continued).

the basement complex (G. tricarinata Zone and lower $A$. cymbiformis Zone, respectively). We recovered $\simeq 34 \mathrm{~m}$ of basaltic rocks and $\simeq 11.6 \mathrm{~m}$ of sedimentary rocks, for a total of $\simeq 45.6 \mathrm{~m}$ of the $80.0 \mathrm{~m}$ cored within the basement complex ( $57 \%$ recovery rate). We believe that the sonic logging accomplished within the basement complex here allows us to reconstruct the hole accurately.

The sonic log within the basement complex is shown in Figure 4. The caliper trace indicates that within the basement complex the hole was reasonably uniform in width and without major washouts. In general, there is a very good correlation between recorded high sonic velocities, low gamma ray activity, and basalt recovery and between recorded low sonic velocities, high gamma ray activity, and sediment recovery. Though a quantitative interpretation will not be given here, we believe that the interval of high gamma ray activity corresponds to the high potassium content of the sedimentary rocks within the basement complex.

We show in Figure 5 what we believe to be our best interpretation of the sonic log. Next to the reconstructed section we show the actual recovery and rock type. Sonic velocities from the well log and from the shipboard physical properties measurements are also included. In reconstructing the hole, we assume, in most cases, that velocities of less than $4.0 \mathrm{~km} / \mathrm{s}$ are of sedimentary origin. Velocities $>4.0 \mathrm{~km} / \mathrm{s}$ are generally assumed to be 


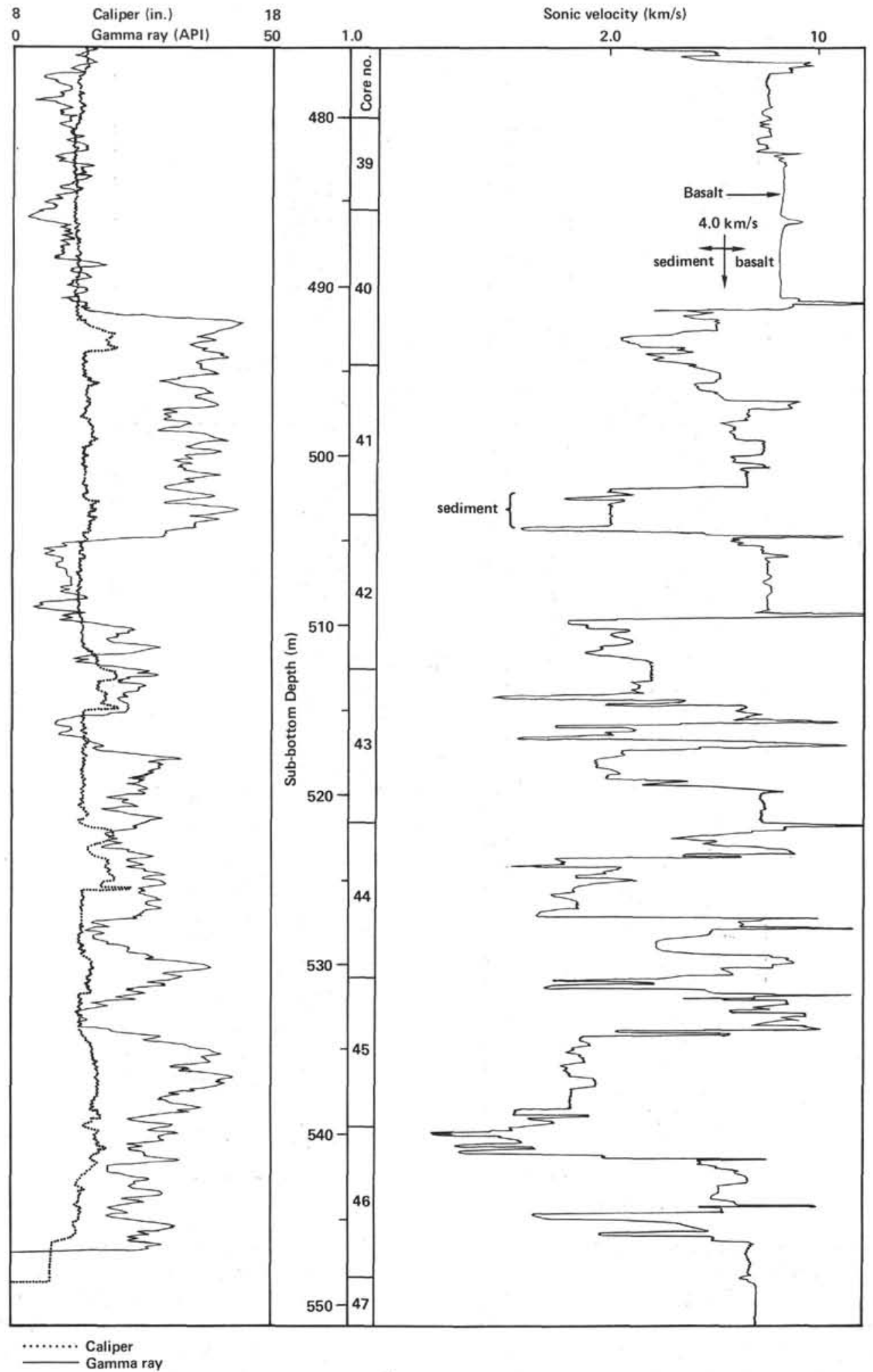

Figure 4. Sonic velocity $\log$ in basement complex at Site 528.

basaltic. For the rock types for which the velocity discrimination was difficult the gamma ray trace and/or recovered samples aided in interpretation. For most of the sonic log, the velocity discrimination was obvious. In general, the velocities to which we assigned a sediment origin were less than $3.0 \mathrm{~km} / \mathrm{s}$. Most of the velocities to which we assigned a basalt origin were $5.0 \mathrm{~km} / \mathrm{s}$ or greater. We note in Figure 5 the excellent agreement between the recovered rocks and those interpreted from the sonic log.

Within the 80 -m basement complex, as noted earlier, we recovered $\simeq 34 \mathrm{~m}$ basalt and $\simeq 11.6 \mathrm{~m}$ of sediment. The interpretation of the well logs is that $38.8 \mathrm{~m}$ of basalt and $36.2 \mathrm{~m}$ of sediment are present in the upper 


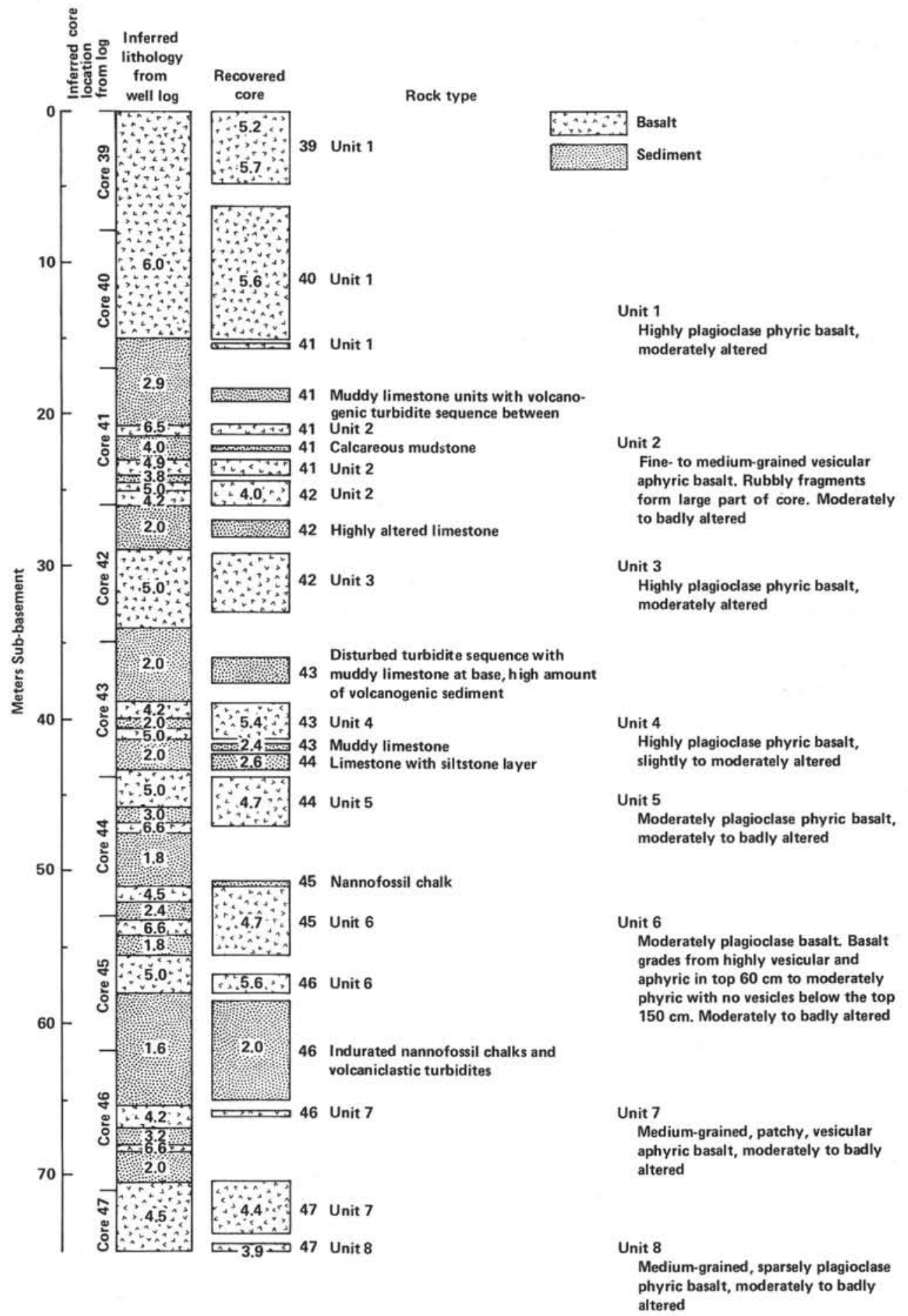

Figure 5. Reconstructed section based on sonic velocity well log and recovered core in the basement complex at Site 528. (Numbers on the lithologic columns indicate the velocity, in $\mathrm{km} / \mathrm{s}$.)

$75 \mathrm{~m}$ of the complex, suggesting that nearly all of the basalt drilled $(88 \%)$ was recovered and that most of the missing section consists of sediments, open fractures, or cavities. Thus, only $32 \%$ of the inferred sediment was recovered.

The comparison of the sonic log to the recovered core has enabled us to distinguish with confidence between grossly different rock types, i.e., sediment versus basalt. Within the basalts, we have a wide range of sonic veloc- ities $(\simeq 4.2$ to $6.6 \mathrm{~km} / \mathrm{s})$. Even though the velocities from the sonic logs generally compare well with what we would expect from the recovered cores, we believe that we would have difficulty in distinguishing between the different basalt units if we had not recovered nearly all of the cored basalts. For example, the badly to moderately altered vesicular aphyric basalts (Units 2 and 7) have velocities similar to the badly to moderately altered and fractured plagioclase phyric basalts (Units 3, 4, 5, 
and 8). The velocities of these units are generally from 4.2 to $5.0 \mathrm{~km} / \mathrm{s}$, with a few thin layers of greater velocity. The massive plagioclase phyric basalt of Unit 1 is characterized by a higher seismic velocity $(6.0 \mathrm{~km} / \mathrm{s})$, as one would expect. Most of the sediment velocities within the basement complex range from 1.6 to $3.0 \mathrm{~km} / \mathrm{s}$. We find little correlation between sediment type and velocity structure, owing most probably to large washouts and poor recovery of these sediments within the basement complex. We consider the rock types with velocities of 4.0 and $3.8 \mathrm{~km} / \mathrm{s}$ near the top of the section (Core 528-41) to be of sediment origin, based on the recovery of a small amount of calcareous mudstone $(0.3 \mathrm{~m})$ in this part of the section. An alternative explanation (and perhaps equally valid) is that the mudstone was not recovered in place, but derives from farther up the hole, and that the 3.8 and $4.0 \mathrm{~km} / \mathrm{s}$ rocks are part of Unit 2, consisting of lower velocity vesicular phyric basalts.

\section{SONOBUOY CRUSTAL SECTION}

A wide-angle reflection/refraction sonobuoy profile was obtained as Glomar Challenger left Site 528. The crustal section obtained from the sonobuoy is given in Figure 6 and Table 2.

We observe from the wide-angle reflection data a 480 -m-thick layer of average velocity $(2.05 \mathrm{~km} / \mathrm{s})$ that corresponds to the sedimentary section from the seafloor to the top of the basement complex. The velocities obtained for this part of the section from the sonic well $\log$ are variable but, in general, increase with depth from $\simeq 1.70 \mathrm{~km} / \mathrm{s}$ to about $2.0 \mathrm{~km} / \mathrm{s}$. The sonic measurements taken aboard ship from the recovered material range from $\simeq 1.55$ to $2.0 \mathrm{~km} / \mathrm{s}$.

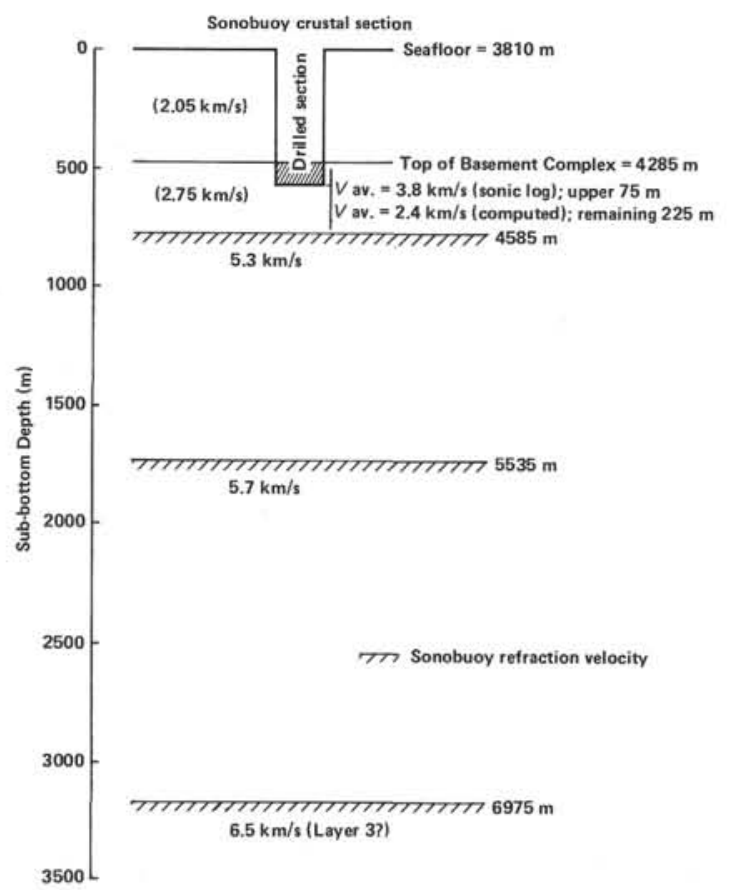

Figure 6. Sonobuoy wide-angle reflection/refraction results shown in relation to drilled section at Site 528. (Interval velocity from sonobuoy wide-angle reflection in parentheses.)
Table 2. Sonobuoy result, Site 528.

\begin{tabular}{ll}
\hline $\begin{array}{c}\text { Layer } \\
\text { Thickness } \\
(\mathrm{km})\end{array}$ & $\begin{array}{c}\text { Velocity } \\
(\mathrm{km} / \mathrm{s})\end{array}$ \\
\hline 3.81 & 1.03 \\
0.48 & $2.05^{\mathrm{a}}$ \\
0.30 & $2.75^{\mathrm{a}}$ \\
0.95 & $5.3 \mathrm{~b}$ \\
1.44 & $5.7 \mathrm{~b}$ \\
& $6.5 \mathrm{~b}$ \\
\hline & \multicolumn{2}{c}{ a Wide-angle } & reflec- \\
tion velocity. \\
b Refraction velocity.
\end{tabular}

The average velocity from the sonobuoy wide-angle reflection data for the $300 \mathrm{~m}$ below the top of the basement complex (between 4285 and $4585 \mathrm{~m}$ below sea level) is $2.75 \mathrm{~km} / \mathrm{s}$ (Fig. 6). We tabulated the velocity and thickness from the sonic well log for each of the layers in the upper $75 \mathrm{~m}$ of the basement complex. An average velocity derived from the integrated transit time data for this upper $75 \mathrm{~m}$ of the basement complex is computed to be $3.8 \mathrm{~km} / \mathrm{s}$. The average velocity of $2.75 \mathrm{~km} / \mathrm{s}$ obtained by the sonobuoy wide-angle reflection method for the upper $300 \mathrm{~m}$ of the basement complex is a value much lower than the logged value for the upper part of this section. We noted earlier that interpretation of the sonic logs in the upper $75 \mathrm{~m}$ of the basement complex suggests that it is composed of $38.8 \mathrm{~m}$ basalt and $36.2 \mathrm{~m}$ sediment. The sonobuoy results thus suggest that the following $225 \mathrm{~m}$ of the basement complex has an even greater percentage of sedimentary rocks (or open fractures or cavities) and thus, fewer basaltic rocks. If we use the same average velocities that we computed from the sonic log for the top $75 \mathrm{~m}$ of the basement complex $(5.3 \mathrm{~km} / \mathrm{s}$ for the basalts and $2.2 \mathrm{~km} / \mathrm{s}$ for the sediments), then the next $225 \mathrm{~m}$ of the basement complex consists of $210 \mathrm{~m}$ sediment and $\simeq 15 \mathrm{~m}$ basalt. If large sediment-free cavities (which are thus lower in velocity) are present within the section, then the amount of computed basaltic material obviously increases.

We observe three refracted arrivals in the sonobuoy data: $5.3 \mathrm{~km} / \mathrm{s}$ at $4585 \mathrm{~m}, 5.7 \mathrm{~km} / \mathrm{s}$ at $5535 \mathrm{~m}$ and $6.5 \mathrm{~km} / \mathrm{s}$ at $6975 \mathrm{~m}$. The 5.3 and $5.7 \mathrm{~km} / \mathrm{s}$ layers most probably represent volcanic material comprising a thickened $(\simeq 2400 \mathrm{~m})$ oceanic Layer 2 . The $6.5 \mathrm{~km} / \mathrm{s}$ velocity at $6975 \mathrm{~m}$ below sea level is similar to that observed for oceanic Layer 3 in the ocean basins (Raitt, 1963).

\section{DISCUSSION AND CONCLUSIONS}

The correlation of the downhole well logs with the recovered sediment is excellent. The clayey area and areas with increased volcanogenic sediment show significant increases in the gamma ray traces. These areas are also identified on the sonic and density logs by a negative spike indicating a decrease in wet-bulk density and sonic velocity. Similarly, the slump deposits and breccias give relatively high gamma ray and low density and sonic velocity readings. Most of the interval from the Creta- 
ceous/Tertiary boundary to the basement complex is identified by relatively high gamma ray values, owing to the enriched amounts of clay and volcanogenic materials found there.

One of the important uses of the downhole logging data is in identifying the rock types in the intervals where recovery is poor. Within the basement complex the comparison of the logs to the recovered cores clearly demonstrates that the boundaries between the major rock types (e.g., sediment versus basalt) are generally distinguishable. The logs that we used here merely detect differences in select physical properties (density at Site 527; sonic velocity at Site 528) of the rocks surrounding the hole. Since these physical properties are not unique to any one rock type, we obviously cannot unequivocally resolve all of the intervals, especially within the basaltic part of the basement complex (e.g., basalts with different chemistries and textures may have similar velocities).

Our reconstruction of the upper $\simeq 75 \mathrm{~m}$ of the basement complex shows that approximately half of the material is igneous and the other half sedimentary in origin. We recovered most of the basalts we drilled $(88 \%)$. We were less successful with the sediments $(32 \%$ recovery) owing most probably to washouts resulting from the large downhole water pressures that accompany drilling through the hard rock.

The seismic reflection records show that the top of the basement complex is smooth in character, compared to oceanic basement generally observed in the world's oceans. The basement consists of basalts intercalated with sediments. Similar observations of "smooth acoustic basement" and recovered basalts with the intercalated sediments were made at Site 462 in Jurassic ocean crust in the Nauru Basin of the western Pacific Ocean (Larson, Schlanger, et al., 1981). It is interesting to note that the intercalated sedimentary units in the Nauru Basin were characterized by abundant contributions of sediment transported and redeposited to the site, in a fashion similar to that observed at Site 528 on the Walvis Ridge.

A smooth basement reflector was drilled at Sites 338 and 342 on the Vфring Plateau bordering the continental margin of Norway (Talwani, Udintsev, et al., 1976). The rocks recovered by drilling showed the smooth basement reflector to be basaltic in origin; it was believed by Talwani and Udintsev (1976) to be the top of oceanic basement. However, subsequent multichannel seismic reflection measurements (Hinz and Weber, 1976) show that in the vicinity of drilling the prominent smooth "basement" reflector is underlain by closely spaced dipping reflectors and that the true oceanic basement lies some distance below the smooth reflector. An important observation off Norway was that the age of the oldest sediments (early Eocene) above the smooth basaltic reflector is in reasonable agreement with the age obtained from magnetic anomalies (between Anomalies 24 and 25). This suggests that the processes active from the time oceanic crust began forming to the time the smooth basement reflector formed occurred very quickly. Talwani and Udintsev (1976) suggest that the basaltic reflector penetrated at Sites 338 and 342 is only slightly younger than the basement underneath and that the intervening reflectors may represent rapidly depositing pyroclastics associated with volcanic activity during the early opening of the Norwegian Sea. We noted earlier that at Site 528 on the Walvis Ridge, the oldest sediments above the basement complex were only slightly younger than those observed in the sediments intercalated within the basalts, at a depth close to $80 \mathrm{~m}$ below the top of the basement complex. A similar observation was made at Site $\mathbf{5 2 5}$ where a lower Maestrichtian-upper Campanian nannofossil zone (Quadrum trifidum zone) was observed just above the basement complex and $\simeq 75 \mathrm{~m}$ below the top of the recovered basalts. Our sonobuoy results suggest that at Site 528 we have $\simeq 300 \mathrm{~m}$ of basalt with intercalated sediments and that the ratio of sediments to basalts increases with depth. Below this 300 -m interval we observe a velocity structure similar to Layers 2 and 3 in the ocean basins.

We believe that our observations with respect to age versus depth within the part of the basement complex that was drilled strongly suggest that the processes forming the upper part of the Walvis Ridge were accomplished rather quickly, a conclusion supportive of the similar results suggested by Talwani and Udintsev (1976) for the Vøring Plateau.

Houtz and Ludwig (1979) report that the southwest Pacific Ocean contains significant accumulations of acoustically reverberant material, called "smooth acoustic basement," that is difficult to penetrate, especially with the small air gun types $\left(328-656 \mathrm{~cm}^{3}\right)$ used in the Walvis Ridge study. They note that the misidentification of the reverberant material as oceanic Layer 2 would result in the attribution of basement depths in places that are in fact up to $2000 \mathrm{~m}$ too shallow. DSDP samples and other velocity information indicate that the reverberant material is volcanogenic in places and calcareous in others (Lancelot and Larson, 1976; Winterer, Ewing, et al., 1973; Larson, 1976). The limited number of repeat seismic profiler traverses with large air guns $\left(7628 \mathrm{~cm}^{3}\right)$ demonstrate that true oceanic basement is situated below the reverberant or smooth acoustic basement. We believe that a similar result will be found if the Walvis Ridge is traversed with a higher energy sound source.

\section{ACKNOWLEDGMENTS}

We wish to thank Captain Clarke and the crew of the Glomar Challenger for their assistance in gathering the data during the logging operation. Robert Houtz assisted in the reduction of the sonobuoy. This work was supported in part by the Deep Sea Drilling Project, JOI, Inc., and the National Science Foundation.

\section{REFERENCES}

Boyce, R. E., 1980. Determination of the relationships of electrical resistivity, sound velocity, and density/porosity of sediment and rock by laboratory techniques and well logs from Deep Sea Drilling Project Sites $\mathbf{4 1 5}$ and $\mathbf{4 1 6}$ off the coast of Morocco. In Lancelot, Y., Winterer, E. L., et al., Init. Repts. DSDP, 50: Washington (U.S. Govt. Printing Office), 305-318.

1981. Electrical resistivity, sound velocity, thermal conductivity, density-porosity, and temperature, obtained by laboratory techniques and well logs: Site 462 in the Nauru Basin of the Pacific 
Ocean. In Larson, R. L., Schlanger, S. O., et al., Init. Repts. DSDP, 61: Washington (U.S. Govt. Printing Office), 743-762.

Ewing, J., and Ewing, M., 1971. Seismic reflection. In Maxwell, A. (Ed.), The Sea (Vol. 4, Pt. 1): New York (John Wiley), 1-51.

Hamilton, E. L., 1965. Sound speed and related physical properties of sediments from experimental Mohole (Guadalupe site). Geophysics, 35:995.

1976. Variations of density and porosity with depth in deep sea sediments. J. Sed. Petrol., 46:280.

Hinz, K., and Weber, J., 1976. Zum geologischen Aufbau des Norwegischen Kontinentalrandes und der Barents-See nach Reflexions seismischen Messungen. Erdol Kohle, Erdg., Petrochem., Compendium, 75/76:3-29.

Houtz, R. E., and Ludwig, W. J., 1979. Distribution of reverberant sub-bottom layers in the southwest Pacific Basin. J. Geophys. Res., 84:3497-3504.

Kirkpatrick, R. J., 1979a. Results of downhole geophysical logging Hole 396B, DSDP Leg 46. In Dmitriev, L., Heirtzler, J., et al., Init. Repts. DSDP, 46: Washington (U.S. Govt. Printing Office), 401-407.

, 1979b. The physical state of the oceanic crust: Results of downhole geophysical logging in the Mid-Atlantic Ridge at $23^{\circ} \mathrm{N}$. J. Geophys. Res., 84:178-188.

Lancelot, Y., and Larson, R. L., 1975. Sedimentary and tectonic evolution of northwestern Pacific. In Larson, R. L., Moberly, R., et al., Init. Repts. DSDP, 32: Washington (U.S. Govt. Printing Office), 925-939.

Larson, R., 1976. Late Jurassic and Early Cretaceous evolution of the western central Pacific Ocean. J. Geomag. Geoelec., 28:219-236.
Larson, R. L., Schlanger, S. O., et al., 1981. Site 462. In Larson, R. L., Schlanger, S. O., et al., Init. Repts. DSDP, 61: Washington (U.S. Govt. Printing Office), 19-394.

Moore, T. C., Jr., Rabinowitz, P. D., and Shipboard Scientific Party, in press. The Walvis Ridge transect, DSDP Leg 74: The geologic evolution of an oceanic plateau in the South Atlantic Ocean. Geol. Soc. Am. Bull.

Pirson, S. J., 1963. Handbook of Well Log Analysis: Englewood Cliffs, N. J. (Prentice Hall).

Rabinowitz, P. D., and Simpson, E. S. W., 1979. Results of IPOD Site Surveys aboard R/V Thomas B. Davie Cruise 388. L-DGO Tech. Rept., JOI, Inc., UCT. Tech. Rept. \#I.

Raitt, T. W., 1963. The crustal rocks. In Hill, M. N. (Ed.), The Sea (Vol, 3): New York (John Wiley), 85-102.

Salisbury, M. H., Donnelly, T. W., and Francheteau, J., 1980. Geophysical logging in Deep Sea Drilling Project Hole 417D. In Donnelly, T., Francheteau, J., Bryan, W., Robinson, P., Flower, M. Salisbury, M., et al., Init. Repts. DSDP, 51, 52, 53, Pt. 1: Washington (U.S. Govt. Printing Office), 705-713.

Schlumberger, Ltd., 1972a. Log Interpretation (Vol. 1), Principles: 1972b. Log Interpretations (Vol. 2), Charts.

Talwani, M., and Udintsev, G., 1976. Tectonic synthesis. In Talwani, M., Udintsev, G., et al., Init. Repts. DSDP, 38: Washington (U.S. Govt. Printing Office), 1213-1242.

Talwani, M., Udintsev, G., et al., 1976. Sites 338-343. In Talwani M., Udintsev, G., et al., Init. Repts. DSDP, 38: Washington (U.S. Govt. Printing Office), 151-388.

Winterer, E. L., Ewing, J. I., et al., 1973. Init. Repts. DSDP, 17: Washington (U.S. Govt. Printing Office). 